\title{
Supply and Demand of Human Resources in Computer Sciences in Costa Rica For Whom the Bell Tolls
}

\author{
Francisco J. Mata, Ariella Quesada \\ Programa de Investigación y Extensión en Tecnología de Información y Desarrollo Escuela de \\ Informática \\ Universidad Nacional de Costa Rica, Heredia, Costa Rica
}

\begin{abstract}
We analyze in this paper the supply and demand of human resources in computer sciences (CS) in Costa Rica. This is done with the aim of validating claims made by the local media about a large deficit of professionals for ICT occupations in this country, in part due to the lack of response of public universities to the needs of the labor market. For this reason, we also analyze the contribution of the universities in the country, in general and considering separately public and private universities. On the supply side, we studied the supply of degrees for the 2001-2013 period. Among the major findings of our study was an increase in the number of university graduates in CS, which is greater than the increase in the total number of academic degrees awarded. This provides evidence that universities in the country are responding positively to the labor market. Furthermore, we found that public universities shared a greater burden in supplying such degrees, considering their smaller number. Furthermore, we found that the structure of degrees awarded by knowledge areas is very similar among these two types of universities, favoring both degrees in social sciences and education, over engineering and basic sciences areas within CS is contained. Such a finding undermines the criticism that public universities, due to their bureaucratic processes, are not capable of responding to the needs of the labor market. On the demand side, we found that the expected demand for the period 2014-2016-using the available data-does not seem to exceed the supply, not providing evidence about the existence of a large deficit, as claimed by local media. However, limitations in the demand data obtained, as well as methodological limitations for measuring the gap between supply and demand, may be affecting this result. These limitations are discussed and solutions to overcome them are presented.
\end{abstract}

\section{Introduction}

Graduates from computer sciences (CS) programs are among the most demanded by Costa Rican organizations $[1,2,3]$. This is evidenced in the study "Monitoring of the Working Condition of the 2008-2010 Graduates from Costa Rican Universities" [4], which reports that the level of unemployment for graduates in CS was $3.76 \%$ for the year 2013. As comparison, the Central Bank of Costa Rica estimated the natural unemployment level for the country in $6.04 \%$ for the year 2012 [5]. Furthermore, the average unemployment rate in the country for the four quarters of 2013 was $9.38 \%$ [6]. Associated with this high demand, media in Costa Rica have reported a deficit of human resources for occupations in information and communication technologies (ICT), which is estimated between 7,000 and 8,000 positions [7,8,9]. This allegation is supported by the Association of Information and Communication Technology Companies (CAMTIC). To put into perspective the relative magnitude of this deficit, the population of Costa Rica was estimated in 4.8 million inhabitants in 2015 [10], and the workforce at the IV quarter of that year in 2.2 million [11].

The gap between supply and demand in human resources, as explained by the media, is associated with problems of the universities -from which, public universities are particularly criticized- to respond adequately to the needs of the labor market. This alleged lack of human resources in CS conflicts with the focus of the country to continue attracting multinational companies -offering technological products and services-, due to its capacity to generate new well-paid jobs and to increase exports. According to CINDE -organization which acts as the national agency for the promotion of foreign investment in the country-, 142 multinational hightechnology companies were located in Costa Rica in 2014. In total, such companies generated over 46,000 direct jobs and registered US\$ 6,048 million in exports for the year 2013, showing exports for this group a remarkable increase from the US\$ 1,682 million reported for the year 1999 [12].

On the other hand, universities claim that they are developing new academic programs in CS [13], and also increasing the enrollment in existing ones [2].

This struggle between ICT companies and universities has existed in the country for several years and dates to the 1990 s, time in which the ICT 
sector in Costa Rica experienced a notable growth [14].

In this context, we analyze the gap between supply and demand of ICT human resources in Costa Rica -focusing on CS university programs-, to validate the claim about the existence of a large deficit of human resources for the ICT sector in the country. In addition, we study differences between public and private universities in the country, with regards to this situation. Based on the results, we provide recommendations.

We focus our study at the university level, without considering the technical and associate ${ }^{1}$ degree programs in CS. This is because information about graduates for such levels is not easily available, unlike information from university graduates. In addition, there is evidence that ICT companies show a preference in recruiting university graduates [14,15]; although, this situation appears to be changing $[16,17]$.

The organization of this work is as follows. The second section presents background information related to previous studies of human resources in the ICT sector in Costa Rica. The supply of human resources at the university level in support of this sector is analyzed in the third section. This section considers first the university graduates from all knowledge areas, and later analyzes CS graduates. For this purpose, historical data is used from 2001 to 2013. The fourth section presents the expected demand for human resources for the ICT sector. We compare the estimates obtained for the supply and demand for the period 2014-2016 in the fifth section. The last section presents the conclusions and recommendations.

\section{Background}

The deficit in ICT human resources is a problem that has worried Costa Rican companies for years. In the late $1990 \mathrm{~s}$, there was concern in the country that the growth in the demand for professionals in the ICT sector -driven by the successful Costa Rican software development industry- would exceed the existing capacity in the country for training professionals in this area. This preoccupation was spearheaded by the juncture of the year 2000 (a.k.a "Y2K") problem, as revealed by data presented by Mata and Jofré [14]. Although this juncture was about to conclude, the growth prospects of the software industry worldwide -coupled with the good positioning that Costa Rican software companies had achieved during that period- worried software entrepreneurs in the country and raised the question of whether the demand for ICT human resources

\footnotetext{
1 This a degree below the bachelor's awarded by colleges and some public universities in the country.
}

would exceed the available supply, limiting the growth of the software industry in the country.

It is for this reason that between 2000 and 2001 the first study of supply and demand of human resources for the software development industry was carried out. This study was promoted by the former Association of Software Producers of Costa Rica (CAPROSOFT) -now transformed into CAMTICwith funding from the Inter-American Development Bank (IDB). Using a survey, this study concluded that for the period 1999-2000 the 137 software companies in the sample used had the capacity of recruiting $18 \%$ of the technical, $24 \%$ of the associate's, $24 \%$ of the bachelor's, $71 \%$ of the licentiate's, ${ }^{2}$ and $46 \%$ of the master's degrees ${ }^{3}$ awarded in CS. The supply data were obtained from the educational institutions in the country and from CONARE -organization that regulates public universities. Considering estimates of growth in supply and demand, it was also determined that just these same companies could hire $29 \%$ of the technical, $33 \%$ of associate's, $41 \%$ of bachelor's, $100 \%$ of the licentiate's, and $70 \%$ of the master's degrees expected in CS during the period 2001-2002. Consequently, the recruitment of CS graduates at university levels showed -in the perception of the respondents- a significant growth for the companies studied. Given the fact that the demand obtained represented a relatively small portion of the Costa Rican organizations that required hiring ICT occupations, this study concluded that if the demand from other companies in the country would be considered, then the total demand could exceed the supply capacity in the country, thus likely generating a deficit [14]. However, the magnitude of the possible deficit was not estimated in this study.

The results of the previous study came during the development of an aggressive policy to promote foreign direct investment in Costa Rica, which resulted in the decision by Intel in the late 90 s to install a series of manufacturing and testing facilities in the country. This decision generated a chain reaction, which led other multinational companies to establish in the country -particularly, IT-enabled service companies-, further increasing the demand for CS occupations [18].

However, the expected increase in the demand for human resources did not fully materialize, due to the slowdown in the ICT sector worldwide, much due to the dot-com bubble at the beginning of the new millennium. Notwithstanding this situation, CINDE reported a lack of 7,500 persons for positions in high-technology companies in the country for the year 2007 [19].

\footnotetext{
${ }^{2}$ This is a degree between the bachelor and masters. It usually requires one year more of study after the bachelor.

${ }^{3}$ Doctoral programs in CS are new in Costa Rica, and did not have yet graduates during the period 2001-2013 studied.
} 
It is at that new juncture that a second study on the supply and demand of human resources for the ICT sector in Costa Rica was again conducted from 2007 to 2009 -led by CAMTIC and funded by the International Development Research Center (IDRC) of Canada [15,20].

In this new study, occupations related to software -like the previous study- were included, but also occupations associated with technical support -also covered by CS programs in the country- were considered [21]. Software occupations reflected the demand of indigenous ICT companies, whereas technical-support professions the demand of ICT multinational companies.

Similar to the previous study, data were obtained for technical, associate, and university degrees in CS (bachelor, licentiate and masters) for the decade 1997-2006 to estimate supply. Following the previous study, a survey was used, which was sent to a sample of 160 Costa Rican companies/organizations selected on an expertjudgment basis (non-random sample) considering their importance for the labor market. From this sample, 83 responses were received: 59 from national ICT companies, 13 from multinational companies related to the ICT sector -most of them established after the previous study was conductedand 11 from national companies/organizations related to other sectors but heavily dependent on ICT, for example banks.

The estimates of supply and demand for CS graduates for the years 2008 and 2009 are shown in Table 1. Based on the results of this study, it was again concluded that a deficit could exist for those years, although as in the previous study the magnitude of the deficit was not estimated. This conclusion was based on the fact that demand estimates did not consider all firms/organizations in the country, while supply estimates considered the entire educational system in the country. It is also important to note that the projected deficit was higher in 2008 than in 2009, because the estimated demand from the participating companies decreased for that year -vis-à-vis the previous one-, and the projected supply increased.

Table 1. Supply versus demand of occupations related to software and technical support (2008-2009)

\begin{tabular}{|l|c|c|}
\hline & $\mathbf{2 0 0 8}$ & $\mathbf{2 0 0 9}$ \\
\hline Supply & 2,734 & 2,857 \\
\hline Demand & 2,413 & 1,251 \\
\hline $\begin{array}{l}\text { Supply minus } \\
\text { demand }\end{array}$ & 321 & 1,606 \\
\hline
\end{tabular}

Source: Adapted from Mata and Matarrita [21]
In addition, the 83 companies participating in the demand study indicated that they were not able to hire 2,299 professionals related to CS occupations during 2007, which was almost equivalent to the estimation of graduates for the entire education system for the same year (2,368 graduates) [15].

\section{Supply of human resources at the university level in Costa Rica}

We use data provided by CONARE -which includes information from both public and private universities - to analyze the supply of CS degrees in Costa Rica, like the previous studies already presented. The period considered was from 2001 to 2013, the latter being the most recent year for which data were available during the time our study was conducted.

\subsection{Supply of university degrees in all areas of knowledge}

Figure 1 shows how the number of university graduates in Costa Rica has grown over the period studied. In the year 2001, universities awarded about 23,000 diplomas, while for the year 2013 this number doubled to around 46,000. In this context, private universities are becoming more important over the years, contributing for the year 2013 about $70 \%$ of the total diplomas awarded. However, this ratio of 2:1 of graduates between private and public universities contrasts with the ratio of $10: 1$ in the number of these universities. This fact demonstrates the importance that public universities in Costa Rican have for the labor market, in numerically terms.

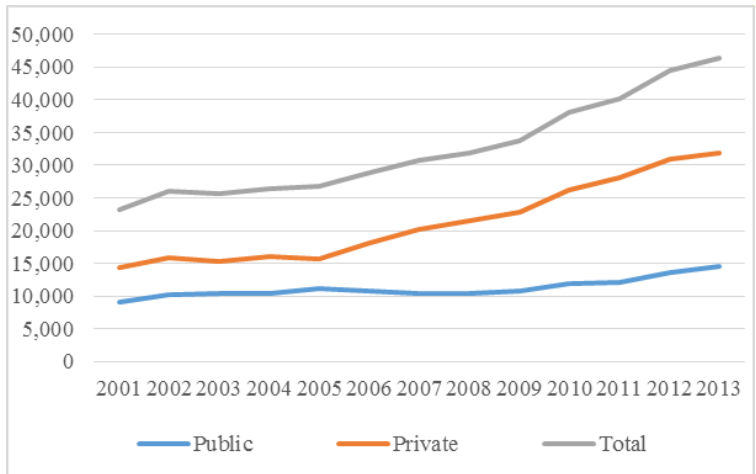

Figure 1. University diplomas awarded in Costa Rica by type of university (2001-2013)

Source: Own elaboration with data from CONARE

Table 2 presents the linear growth trends for the diplomas awarded by the Costa Rican universities. The linear growth rate for all universities is 1,873 diplomas per year for the period 2001-2013. Private universities present a linear growth rate of 1,540, while public universities a rate of 333 . 
Table 2. Linear growth trends for diplomas awarded in Costa Rica by type of university (2001-2013)

\begin{tabular}{|l|l|c|}
\hline Universities & \multicolumn{1}{|c|}{ Linear regression } & $\mathbf{R}^{\mathbf{2}}$ \\
\hline All & $\mathrm{y}=1,872.89 \mathrm{x}+19,430.00$ & 0.94 \\
\hline Private & $\mathrm{y}=1,539.73 \mathrm{x}+10,521.15$ & 0.93 \\
\hline Public & $\mathrm{y}=333.16 \mathrm{x}+8,908.85$ & 0.74 \\
\hline \multicolumn{2}{|c|}{ Source: Own elaboration with data from CONARE }
\end{tabular}

Figure 2 presents the percentage of diplomas awarded by all universities in Costa Rica, according to areas of knowledge. This figure shows that $70 \%$ of all the diplomas awarded for the period 20012013 , on average, focused on areas related to social sciences and education. It can also be observed that while degrees in social sciences exhibited growth during 2009-2013, degrees in education showed a decrease during this five-year period.

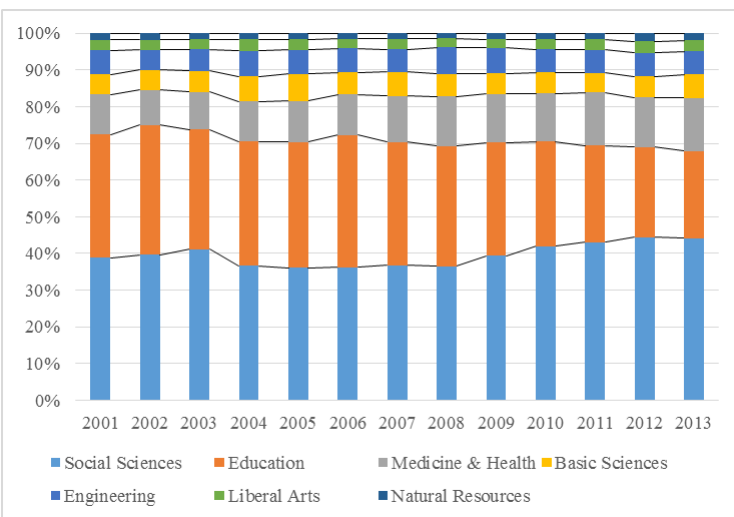

Figure 2. University diplomas awarded in Costa Rica by area of knowledge (2001-2013)

Source: Own elaboration with data from CONARE

The previous figure clearly shows that there is less preference to study academic programs related to engineering and basic sciences, within which CS are included. In this regard, the percentage of diplomas awarded in these areas remains relatively constant, as shown in the same figure. On average these areas had a contribution of $6.41 \%$ and $6.04 \%$, respectively, over the period studied.

Figures 3 and 4 present the percentage of diplomas awarded according to areas of knowledge for public and private universities, respectively. These figures present a similar pattern to Figure 2. On average, the number of diplomas combining social sciences and education for the 2001-2013 is $65 \%$ for public universities and $74 \%$ for private universities. However, it should be noted that public universities proportionately awarded, on average, more diplomas than private universities in engineering $(8.50 \%$ versus $5.28 \%)$, as well as in basic sciences $(8.90 \%$ versus $4.51 \%)$.

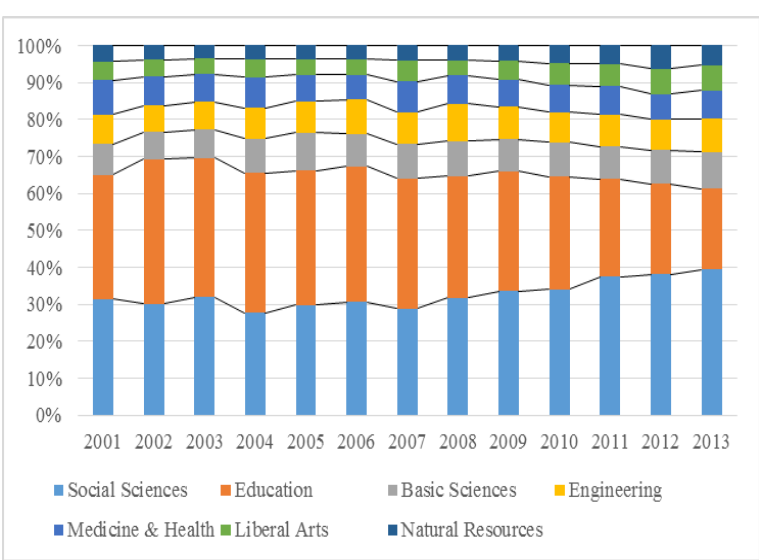

Figure 3. Diplomas awarded by public universities and area of knowledge (2001-2013)

Source: Own elaboration with data from CONARE

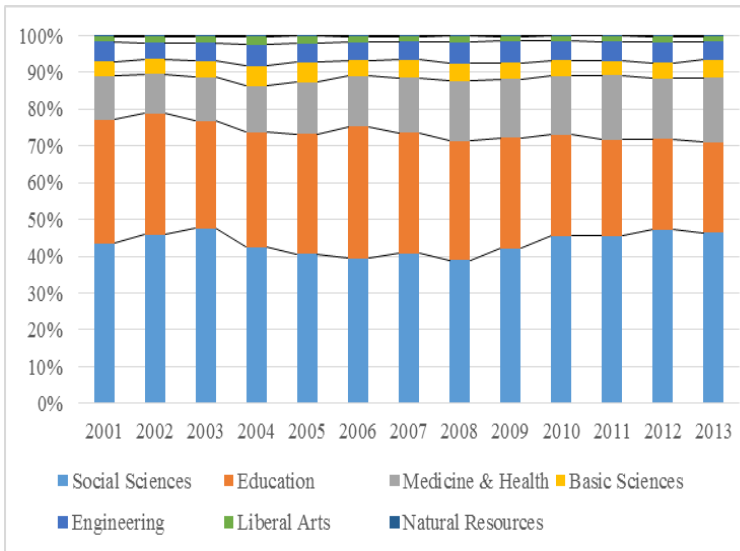

Figure 4. Diplomas awarded by private universities by area of knowledge (2001-2013)

Source: Own elaboration with data from CONARE

These results undermine the criticism often made to public universities for being very bureaucratic. and so incapable of reallocating the public resources they receive to provide more spaces -which eventually would be reflected in more diplomas- in science and technology programs in response to a greater demand in the labor market for graduates from such areas. If such demand were so evident, private universities would already have established a diploma structure favoring more this type of programs, given the fact that not only private universities are more capable of reacting faster to changes in the labor market, but their viability depends on their effective response to this market.

The above is related to the fact that unemployment for 2013 was $6.9 \%$ in social sciences and $4.7 \%$ in education, yet only $3.5 \%$ in engineering and $3.8 \%$ in basic sciences. Therefore, although from an economical point of view would be better to pursue engineering and basic science -than social science and education- programs, students do not perceive it in this way. A lack of interest in engineering and basic sciences from high school 
students, particularly women, may explain this situation [22].

Figure 5 shows the number of engineering and basic science diplomas by type of university for the period 2001-2013.

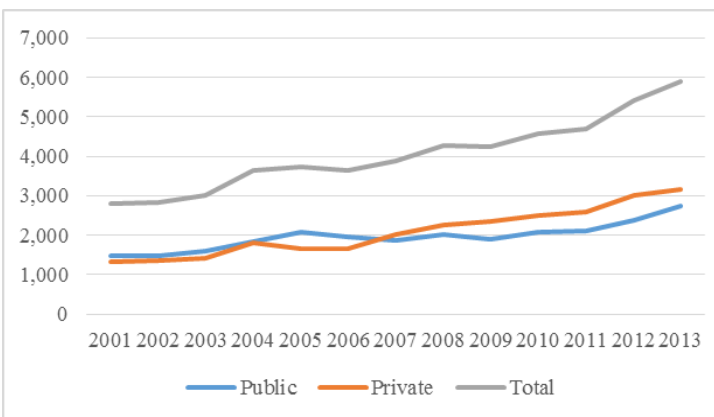

Figure 5. Diplomas awarded in engineering and basic sciences by type of university (2001-2013) Source: Own elaboration with data from CONARE

\subsection{Supply of CS graduates}

Figure 6 presents the total number of diplomas awarded in CS in Costa Rica. As shown, the number of these diplomas for all universities increased from 944 in 2001 to 2,344 in 2013, representing a growth of $148 \%$. In comparison, the total number of diplomas for all universities increased $99 \%$ during the same period.

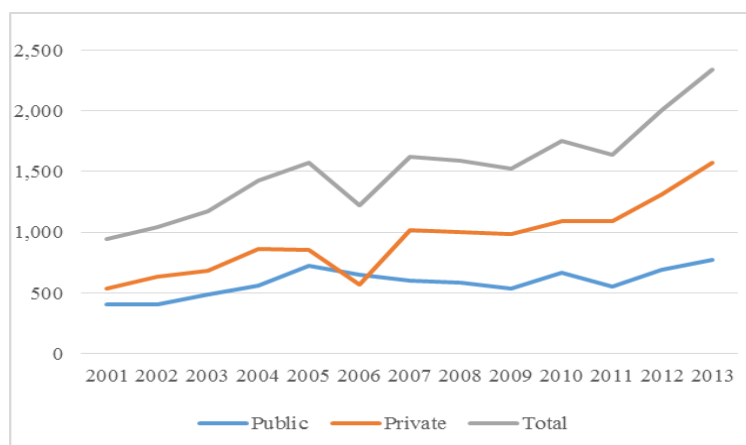

Figure 6. CS diplomas awarded in Costa Rica by type of university (2001-2013)

Source: Own elaboration with data from CONARE

From the 2,344 diplomas in CS awarded in 2013, private universities accounted to 1,574 whereas public universities to 770 . This ratio of $2: 1$ in CS degrees from private to public universities contrasts with the ratio of $3.4: 1$ in the number of private to public universities offering CS degrees. Therefore, proportionately the contribution of CS degrees is higher for public universities, considering their number.

As Table 3 presents, 90 new CS degrees are expected every year: 69 by private universities and 21 by public universities.
Table 3. Linear growth trends for CS diplomas awarded in Costa Rica by type of university (20012013)

\begin{tabular}{|l|l|l|}
\hline Universities & Linear regression & $\mathbf{R}^{2}$ \\
\hline All & $\mathrm{y}=89.86 \mathrm{x}+899.27$ & 0.82 \\
\hline Private & $\mathrm{y}=69.13 \mathrm{x}+456.96$ & 0.82 \\
\hline Public & $\mathrm{y}=20.74 \mathrm{x}+442.31$ & 0.50 \\
\hline
\end{tabular}

Source: Own elaboration with data from CONARE

On the other hand, Figure 7 shows that the highest number of CS diplomas awarded Costa Rica corresponds to the bachelor's degree, which has the highest growth during the period studied (see Table 4). Previous studies have determined that this academic degree is the most important for the ICT sector in Costa Rica [14,15].

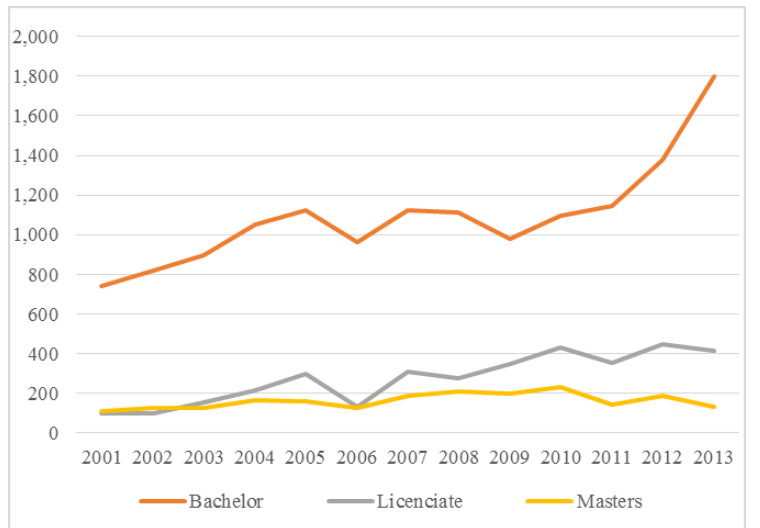

Figure 7. CS diplomas awarded in Costa Rica by degree (2001-2013)

Source: Own elaboration with data from CONARE

Table 4. Linear growth trends for CS diplomas awarded in Costa Rica by degree (2001-2013)

\begin{tabular}{|l|l|l|}
\hline Degree & \multicolumn{1}{|c|}{ Linear regression } & \multicolumn{1}{|c|}{$\mathbf{R}^{2}$} \\
\hline Bachelor & $\mathrm{y}=55.76 \mathrm{x}+703.35$ & 0.66 \\
\hline Licenciate & $\mathrm{y}=29.34 \mathrm{x}+69.04$ & 0.84 \\
\hline Master $^{4}$ & $\mathrm{y}=4.76 \mathrm{x}+126.88$ & 0.24 \\
\hline
\end{tabular}

Source: Own elaboration with data from CONARE

Pinto et al. [15] found that the base of the supply for occupations related to software and technical support occupations lies on the bachelor's degrees, and not on the technical and associate degrees. Figure 8 compares this pyramid in 2006 -presented by the previous researchers-, with the corresponding pyramid for the year 2013 -based on the results of our study-, considering only the academic degrees. As shown in this figure, such pyramid from 2006 to

\footnotetext{
4 Regression coefficients for master's diplomas may not be reliable since $\mathrm{R}^{2}$ is very low.
} 
2013 presented an increase for the bachelor's and licentiate's, but a reduction for the master's, degrees.

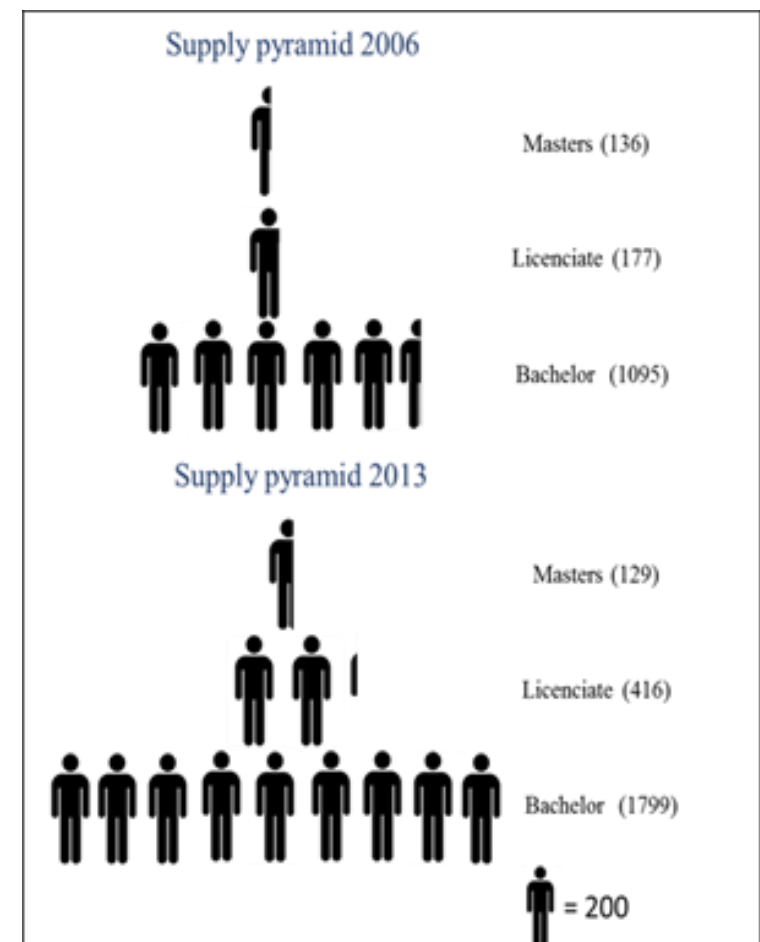

Figure 8. Supply pyramids for CS diplomas in Costa Rica (2006 and 2013)

Source: Own elaboration with data from Pinto et al. [15] and CONARE

The number of bachelor's diplomas in $\mathrm{CS}$ is presented in Figure 9. As shown in this figure, most of the graduates after 2006 were awarded by private universities. For 2013, private universities contributed 1,150 such degrees, whereas public universities 650 . The ratio of contribution of private to public universities $(1.8: 1)$ is slightly lower than that found for all CS degrees in the same year $(2: 1)$, showing public universities proportionately a larger contribution to this degree.

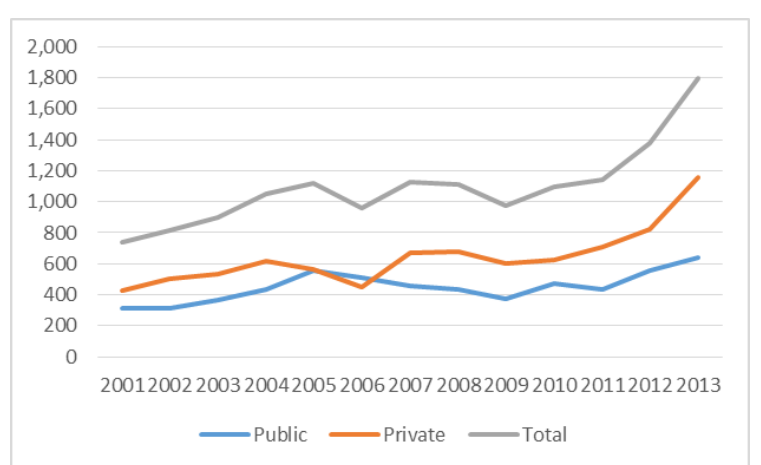

Figure 9. Bachelor's diplomas in CS awarded in Costa Rica (2001-2013)

Source: Own elaboration with data from CONARE

The annual linear growth for the bachelor's degrees in CS for the period 2001-2013 is 56 diplomas (see Table 5). Private universities contribute 39 , while public universities 17 , new such degrees yearly. The difference in the growth rates between private and public universities for this degree is smaller than that found for all CS degrees.

Table 5. Linear growth trends for CS bachelor's diplomas awarded in Costa Rica (2001-2013)

\begin{tabular}{|l|l|l|}
\hline Universities & Linear regression & $\mathbf{R}^{2}$ \\
\hline All & $\mathrm{y}=55.76 \mathrm{x}+703.35$ & 0.66 \\
\hline Private & $\mathrm{y}=38.54 \mathrm{x}+373.15$ & 0.63 \\
\hline Public $^{5}$ & $\mathrm{y}=17.23 \mathrm{x}+330.19$ & 0.47 \\
\hline
\end{tabular}

Source: Own elaboration with data from CONARE

\section{Demand of CS graduates}

We conducted early in 2015 a survey aimed at ICT companies in Costa Rica to determine the demand for human resources in CS. Nevertheless, we obtained a very low response rate for that survey. The explanation for this result was that almost at the same time CAMTIC carried out -in conjunction with the Costa Rican Trade Promotion Agency (PROCOMER)- the Digital Technologies Sector Survey [23], and CINDE also conducted another survey of multinational companies. Since the companies in these three studies were basically the same, they were reluctant to participate again in another survey.

To overcome this problem, we requested CAMTIC to provide us the data corresponding to human resources from its survey, to which this organization agreed. Although, CAMTIC's survey was not specifically intended for a supply and demand study of human resources, the data collected could be used for this purpose.

The sample for this survey was obtained from a database of 897 Costa Rican ICT companies. From this total number, 606 companies were contacted, and 219 companies replied $36 \%$ response rate and $24 \%$ of the population contained in the database) [23].

Descriptive data on the sample obtained for this survey indicated that $37 \%$ of the participating companies were micro enterprises (1-5 employees), $46 \%$ small enterprises (6-30 employees), 12\% medium-sized enterprises (31-100 employees), and 5\% large companies (more than 100 employees). Almost half $(47 \%)$ of the companies had exports, with international sales made primarily to Central America and the United States [23].

Processing the data in CAMTIC's survey, we obtained that the companies participating would

\footnotetext{
5 Regression coefficients for bachelor's degrees may not be reliable since $R^{2}$ is low.
} 
require 1,016 new ICT positions for the period 20142016, mostly demanding a bachelor's degree in CS.

\section{Supply versus demand of human resources in CS at the university level in Costa Rica}

When comparing the estimated supply of bachelor's in CS for the period 2014-2016 -using the linear regression equation presented in Table 4- with the demand computed from the companies participating in CAMTIC's survey -previously presented-, a surplus of 3,603 graduates is obtained (see Table 6). An estimated demand of 4,161 professionals for the period 2014-2016 can be extrapolated for the whole population -assuming the sample obtained was representative. ${ }^{6}$ Under this scenario, a surplus of 458 graduates would still exist. As the ICT sector is the most intensive in hiring CS professionals, it is not evident that other sectors not related to ICT would add such a difference to account to the 7,000-8,000 deficit reported by the media, and defended by CAMTIC on the basis of its own survey (see [9]).

Table 6. Expected Supply versus Demand of Occupations related to CS in Costa Rica (2014-2016)

\begin{tabular}{|c|c|}
\hline & $2014-2016$ \\
\hline Supply & 4,619 \\
\hline Demand & 1,016 \\
\hline Supply minus demand & 3,603 \\
\hline
\end{tabular}

Discussing these results with CAMTIC's Board of Directors in November 2015, they claimed that their survey had two drawbacks. First, it was not possible to obtain information from several multinational companies in the country, which supposedly require a considerable number of ICT staff. Second, their database did not contain information about companies that are not formally registered in the country. According to them, there is evidence of a large degree of informality in the sector since many companies -particularly foreignhire Costa Rican freelance programmers. In view of this situation, CAMTIC's officials alleged that their survey turned out not to be representative in terms to human resources. In this way, they contradicted the assertion presented in the publication of their own survey, in which they claim that it aims at providing a "characterization of the companies, ... including ... human capital" [23, p. 10].

\footnotetext{
${ }^{6}$ This estimate was obtained for the 897 companies in CAMTIC's database using the rule of three.
}

\section{Conclusions and recommendations}

As explained in section 3, the supply of diplomas in CS during the period 2001-2013 increased 148\% for all universities in Costa Rica. This growth is higher than the one observed for all diplomas obtained in these educational institutions (99\%). Therefore, universities in Costa Rica are responding positively to the labor market related to ICT occupations.

Notwithstanding, this growth could have been higher, the same seems to be limited more by the preferences of the students in the country for social sciences and education programs, rather than by the capacity of the universities - particularly public-, as the similarity in the degree structures by public and private universities demonstrate.

Despite the lower unemployment rates in engineering and basic sciences, students in Costa Rica favor more social science and education programs, with greater such rates. Lower unemployment is a clear signal of greater demand in the labor market. Nevertheless, lack of interest in engineering and basic sciences from high school students, particularly women, may explain this situation, as previously explained. Therefore, policies are required to motivate more students to pursue technological programs and to reduce the gender gap in CS, which has been documented in Costa Rica (see [24]).

Furthermore, public universities shared a greater burden in supplying CS graduates, considering their smaller number.

These results undermine the criticism often made to public universities that they are not capable of responding to the needs of the labor market, since they are too bureaucratic.

On the other hand, the demand estimate obtained from CAMTIC's Digital Technologies Sector Survey does not provide evidence that a large deficit for ICT occupations -as announced by the local media and supported by CAMTIC- exist. Such figure arose from CINDE's estimate in 2007 (see [19]) and has not changed for at least nine years (see [9]). During this period, there has been an increase in the number of multinational ICT-related companies in the country, which would not have been possible with scarce human resources.

A word of caution, however, is needed. In studies of this nature, the estimation of demand is the most problematic part due to several reasons. First, a survey to estimate demand for human resources in ICT related occupations should necessarily consider every company/organizations in the country, due to the pervasive nature of ICT. This requires considering a very large population, which is difficult and costly to enumerate. Second, the response rate in studies of this kind is relatively low, as shown by the same survey carried out by 
CAMTIC. This situation can bias the resulting sample, making it difficult to obtain results that can be considered representative. Third, estimates of future human resource demand may be affected by overconfidence on the part of the respondents about business growth or by the desire to count with an excess of supply to reduce labor costs. It is, therefore, important in this type of studies to complement the demand projections with data on the actual number of professionals that have not being recruited at a specific time due to lack of potential employees, as considered in the study conducted by Pinto et al. [15] and contemplated in our proposed demand survey. Therefore, the analysis of supply and demand in ICT requires more comprehensive and therefore, more expensive- studies to address the above-mentioned problems.

However, supply and demand studies only provide an indication of the situation regarding human resources. Interaction between several actors determine the dynamics of CS labor market: public universities, private universities, ICT companies, and government agencies. Such process requires planning, monitoring, and decision-making, not facing a single of these actors the whole responsibility for securing an adequate supply and demand of human resources in CS in Costa Rica [25].

Therefore, paraphrasing Donne, ${ }^{7}$ we can say that:

None of these actors is an island, every one of them is part of the whole. Therefore, never send to know for whom the bell tolls; it tolls for all them.

Consequently, these actors must join efforts to carry out supply and demand studies of human resources for the ICT sector in the country. So far, related studies have been conducted without the active participation of all actors. Such participation would not only mitigate the limitations of such studies but also increase the awareness about the situation and facilitate action.

In this regard, Mata and Quesada [25] recommend the creation of a national commission on ICT human resources, with active participation of actors from the business, academic and governmental sectors.

Better studies are needed to develop policies and implement a concerted action plan to sustain the development of the ICT sector in Costa Rica.

\section{References}

[1] La República, 'Ataque el desempleo, estudie $\begin{array}{lll}\text { ingenierías’, } & 7 & \text { September } \\ \end{array}$

${ }^{7}$ It refers to the poem 'Meditation XVII' written by John Donne in 1624 and included in Devotions Upon Emergent Occasions. https://www.larepublica.net/noticia/_ataque_el_desem pleo_estudie_ingenierias/.

[2] El Financiero, 'Creciente demanda de técnicos reta a la academia', 25 September 2013. http://www.elfinancierocr.com/tecnologia/Tecnicosdemanda-oferta_0_359964030.html.

[3] El Financiero, 'Oferta académica en sector software se queda corta en Costa Rica', 30 March 2014. http://www.elfinancierocr.com/tecnologia/Softwareoferta_academica-universidades-demanda laboral_0_490151007.html

[4] CONARE (2015), Seguimiento de la Condición Laboral de las Personas Graduadas 2008-2010 de las Universidades Costarricenses, Consejo Nacional de Rectores: San José, Costa Rica.

[5] BCCR (2012), 'Estimación de la Tasa de Interés Real Neutral y la Tasa Natural de Desempleo para la Economía Costarricense', Banco Central de Costa Rica: San José, Costa Rica.

[6] INEC, 'Cifras del Empleo', Instituto Nacional de Estadistica y Censos; www.inec.go.cr (29 November 2016).

[7] La Nación, 'Ingenieros y técnicos de Intel Costa Rica salen a buscar trabajos', 9 April 2014. http://www.nacion.com/economia/empresarial/Ingeni eros-tecnicos-salen-buscar-trabajos_0_ 1407459281.html.

El Financiero, 'Elevar oferta de informáticos requerirá de un esfuerzo adicional en la academia', 31 January 2016. http://www.elfinancierocr.com/ tecnologia/Camtic-UCR-UNA-ITCR-CenfotecUlacit-empleo_0_893310680.html.

[8] La Nación, 'Sector de TIC ofrece cuatro plazas por cada estudiante graduado, 16 August 2016. https://www.nacion.com/economia/negocios/sectorde-tic-ofrece-cuatro-plazas-por-cada-estudiantegraduado/5RXKKU7JARHAZCHVAHSFUDRBCY/ story/.

[9] World Bank, 'Population, Total'; https://data.worldbank.org/indicator/SP.POP.TOTL?1 ocations $=$ CR (12 October 2016).

[10] INEC, Costa Rica: Población según Indicadores Generales de la Condición de Actividad; http://www.inec.go.cr/sites/default/files/documetosbiblioteca-virtual/reempleoececomparacion-ivtri2015-01.xlsx (12 October 2016).

La Nación, 'País aloja a 142 empresas de servicios de tecnología', 9 October 2014. http://www.nacion.com/ economia/empresarial/Costa-Rica-empresasservicios-tecnologia_0_1444055605.html.

[11] El Financiero, 'Universidades de Costa Rica en deuda con carreras tecnológicas', 6 October 2014. http://www.elfinancierocr.com/tecnologia/carreras_te cnologicas-universidades-demanda-oferta_0_ 275972427.html. 
[12] F. J. Mata, and A. Jofré (2001), Informe Final del Estudio de Oferta y Demanda del Recurso Humano, Programa de Apoyo a la Competitividad del Sector de Desarrollo de Software en Costa Rica: San José, Costa Rica.

[13] C. Pinto, R. Herrera, F. Mata, R. Matarrita, I. Salas and E. Jara (2009), Formación de Capital Humano en el Sector TIC en Costa Rica, FLACSO/Centro Internacional de Investigaciones para el Desarrollo: Mexico.

[14] La Nación, 'Costa Rica arrastra carencia de técnicos de alta especialización', 18 October 2014. http://www.nacion.com/economia/empresarial/CostaRica-carencia-tecnicos-especializacion 0_1445855435.html.

La Nación, 'Mitad de empresas están hambrientas de técnicos', 13 April 2015. http://www.nacion.com/ nacional/educacion/Mitad-empresas-hambrientastecnicos_0_1481251874.html.

[15] F. J. Mata and G. Mata Marín (2008), 'Foreign direct investment and the ICT cluster in Costa Rica: Chronicle of a death foretold?', in Proceedings of the Sixth International Conference 2008 of the Global Network for the Economics of Learning, Innovation and Competence Building Systems (Globelics), Mexico. http://smartech.gatech.edu/handle/

$1853 / 36914$.

[16] La Prensa Libre, 'Empresas de tecnología enfrentan carencia de recurso humano', 13 July 2007.

[17] F.J. Mata, R. Matarrita and C. Pinto (2012), 'Assessing Computer Education in Costa Rica: Results of a Supply and Demand Study of ICT Human Resources', CLEI Electronic Journal, 15 (1). http://www.scielo.edu.uy/scielo.php?pid=S0717$50002012000100006 \&$ script=sci_arttext\&tlng=pt.

[18] F.J Mata and R. Matarrita (2008), Análisis de la Demanda de Ocupaciones Relacionadas con Software y/o Soporte Técnico para el Periodo 2007-2009, CAMTIC/FLACSO-IDRC: San José, Costa Rica.

[19] El Financiero, 'Sector TIC clama para atraer la atención de los técnicos', 26 April 2016. http://www.elfinancierocr.com/tecnologia/TIC-INAMicitt-demanda-laboral-profesionales-tecnicosCamtic_0_925707433.html.

[20] CAMTIC - PROCOMER (2015), Mapeo Sectorial de Tecnologías Digitales 2014, Cámara de Tecnologías de Información y Comunicación - Promotora del Comercio Exterior de Costa Rica: San José, Costa Rica.

[21] F.J. Mata, A. Quesada and G. Marín Raventós (2012), 'Gender gap in computer science programs from Costa Rican public universities: Are women really becoming extinct?', in Proceedings of the XXXVIII Conferencia Latinoamericana en Informática, CLEI: Medellín, Colombia.

[22] A. Quesada Rosales and F.J. Mata Chavarría (2017), 'Interaction of Actors in the Sectorial ICT Innovation
System in Costa Rica', Latin American Journal of Business Management, 8 (1), pp. 149-172. 